\title{
Price Intransparency, Consumer Decision Making and European Consumer Law
}

\author{
Willem H. van Boom
}

Received: 23 November 2010 / Accepted: 7 June 2011 /

Published online: 28 June 2011

(C) The Author(s) 2011. This article is published with open access at Springerlink.com

\begin{abstract}
Price comparison is a basic element of competition. For comparison to work, at least prices need to be transparent. Moreover, price is usually a focal point in consumer thinking and deciding on transactions. Hence, obfuscating prices can be detrimental to consumers. Therefore, it is vital for policymakers to know how transparent pricing is in reality. Commercial practices involving price intransparency can be detrimental to consumer decision making and may be associated with market failure. So, legislative intervention to ensure price transparency is sometimes warranted. Suppliers may disclose and frame pricing information in such ways as to influence consumers. For some suppliers, advantages may be gained by obfuscating pricethrough practices ranging from the outright hiding of price terms in the small print to subtle ways of throwing in gifts or adding charges during the vending process. Do consumers appreciate the implications of the fact that by framing price in different ways suppliers actually try to influence their demand for products? And how does the law broadly speaking respond to problems of price intransparency? In this article, behavioural science insights are combined with a legal analysis of European consumer law in order to chart some of the detrimental influences of price intransparency on the consumer decision-making process and to answer whether and to what extent European consumer law addresses these issues. In doing so, this article first reviews research from consumer psychology, marketing, and behavioural law, and economics regarding the influence of presentation, framing, and transparency of price on the consumer decision-making process. Subsequently, it describes and evaluates the legal framework offered by European consumer law and how this framework responds to practices of price intransparency. Particular problematic pricing techniques are identified and discussed. In conclusion, attention is drawn to the disadvantages of the increasing full harmonization character of European consumer law for combating price intransparency at Member State level.
\end{abstract}

Keywords Consumer Decision Making · Framing and Anchoring · Bounded Calculation Abilities · Bundling $\cdot$ Lock-in

W. H. van Boom $(\bowtie)$

Rotterdam Institute of Private Law, Erasmus School of Law, Erasmus University Rotterdam, Burgemeester Oudlaan 50, P.O. Box 1738, 3000 DR Rotterdam, The Netherlands

e-mail: vanboom@law.eur.nl 
Price transparency can be considered to be one of the preconditions of the adequate functioning of market economies. Complete price transparency facilitates comparison and makes demand tremendously price sensitive. Therefore, suppliers may have an incentive to make comparison more difficult by obfuscating price and making the price a "maize" as part of their attempt at manipulating consumer preference (Carlin 2009). Such obfuscation techniques may confuse consumers and thus raise consumer search costs (Ellison and Fisher Ellison 2009; Ramsay 2007). The higher the search costs, the less likely consumers are to embark upon searching and comparing price. ${ }^{1}$ Instead, they may tend towards focusing on other propensities of the product. Moreover, inexperience in young consumers and novelty of the marketed product may further add to the impact of obfuscation practices.

Hence, obfuscating price can be detrimental to consumers. Commercial practices involving price intransparency can be detrimental to consumer decision making and may be associated with market failure. For some suppliers, advantages may be gained by obfuscating price - through practices ranging from the outright hiding of price terms in the small print to subtle ways of throwing in gifts or adding charges during the vending process. Consumers may not always appreciate the implications of the fact that by framing price in different ways suppliers actually try to influence their demand for products.

For policymakers, it is vital to know how pricing practices actually work, how consumers respond and whether the applicable legal framework in fact addresses these pricing practices. Traditionally, in legal writing, little attention is given to these aspects. This article fills that gap by combining behavioural science insights with legal analyses of European consumer law. First, it reviews research from consumer psychology, marketing, and behavioural law, and economics regarding the influence of presentation, framing, and transparency of price on the consumer decision-making process. This review sheds light on how consumers perceive and process price information and how suppliers make use of these cognitive processes in the marketing and sales process. Secondly, it analyses the legal framework set forth by European Union (EU) Directives pertaining to B2C marketing and sales and the way this framework regulates pricing information, how it responds to practices of price intransparency and to what extent it combats unfair pricing techniques. Particular problematic pricing techniques are identified and discussed. In conclusion, I draw attention to the fact that only limited room is available to EU Member States to develop general rules on pricing transparency.

\section{Short Typology of Consumer Thinking and Deciding}

It is a trite observation that consumers are boundedly rational decision makers and that limits to their cognitive abilities influence their thinking and deciding in making contract. For instance, there are limitations to human information processing and working memory (Simon 1955). By giving consumers more information, the quality of consumer decision making does not necessarily improve. Furthermore, the ability to shape preferences is both limited and subject to comparison and may therefore be influenced adversely when choice increases beyond the point of saturation (Bettman et al. 1998; Markman and Loewenstein 2010; Schwartz 2004). So, focusing on a single portion of available information may be a

\footnotetext{
${ }^{1}$ The result of adding price complexity may thus be price dispersion for essentially homogenous products. Hence, price dispersion for such products may be a sign of market failure. Cf. Carlin (2009).
} 
strategic response to overcome information overload. Using mental short cuts (such as a preferring top brands over cheaper but equally suitable alternatives, thinking that price indicates quality, following "expert" advice given by the vendor) as well as context (attitudes and opinions of family and peers, availability of products) may be considered a valid coping strategy. Indeed, it seems that when the cognitive load increases (e.g., because of complex pricing structure), individuals tend to use less of the available information (Bettman et al. 1998; Henry 2005). All this can be summarized as follows: for understandable reasons, rather than maximizing their utility, consumers may take on strategies aimed at "satisficing."

The consequence of all this may be that consumers may either undervalue or overrate the importance of price in their decision-making process. The latter can occur whenever consumers hold price to represent quality even when in fact price and quality of the product may be uncorrelated (Chen et al. 2009; Hanf and von Wersebe 1994; Kirchler et al. 2010; Sutton and Riesz 1979). The former occurs whenever context and personal attributes cause consumers to focus on more poignant features than price. Or as Liu and Soman state:

"Price is undoubtedly one of the most important market variables. Given the human complexity in psychological processes and limitations in cognitive capabilities, it is not surprising to see that traditional economic theory and normative choice models often fall short in explaining consumer choice and consumption. This is especially true because consumers never treat prices at their face value, but instead embed them in a broader context and attribute meaning above and beyond the notion of the monetary loss they create" (Liu and Soman 2008).

Still, these broad assertions on thinking and deciding in "the" consumer are in need of further nuances. Consumers are individuals and therefore not identical; their cognitive skills and indeed their subjectively felt need for cognition may differ: whereas some may spend much time and effort in processing information before making decisions, others may not bother so much and rather resort to their "fast and frugal" short cuts to speed up the decision-making process. Perhaps the concept of consumer thinking and deciding should be considered as a sliding scale between two opposites at the far ends. Indeed, contemporary empirical consumer studies categorize consumers into distinct groups with different patterns of thinking and deciding. Increasingly, consumers with a high need for cognition (NFC) and those with a low need for cognition are distinguished. At the one end of the spectre, consumers with high NFC enjoy the task of calculating, comparing, analysing, et cetera, in the consumption process. At the other end, consumers with a low NFC shirk such tasks and employ basic strategies in consumption thinking and deciding.

So, consumers are not identical but it does seem that we can roughly classify them: some display high NFC and others a low NFC. Possibly, low NCF consumers are easier to manipulate than high NFC consumers. For instance, observe what happens if one puts up a display in a supermarket advertising a product as "reduced" while leaving the price unchanged. Some consumers will actually change their choice behaviour and are more likely to buy the item even though the price has remained unchanged. These consumers may have a low NFC. While high NFC consumers are intrinsically motivated to engage in cognitive endeavours, the low NFC consumers are less so inclined. They turn out to be more likely to change their choice behaviour when the promotion sign is used and price is unchanged. So, possibly, minimizing cognitive processing efforts in NCF consumers affects the effective processing of price as a singular piece of information (Inman et al. 1990, 1993). 


\section{Means of Influencing Consumer Decision Making}

\section{"Behavioural Pricing"}

There is ample knowledge on factors which influence the consumer decision-making process. For instance, adding time pressure may distract from price information. Using preticked boxes in internet sales may cause low NCF consumers to overlook the marketing technique of "partitioning price" (e.g., by adding on secondary products and services such insurance, warranty extension, servicing, pretesting, gift wrapping).

It is worthwhile to briefly report here on this line of research. Some of the findings showing these influences are based on the well-known strand of psychological research on frames, anchors, and biases for price transparency. This line of research refutes a number of the behavioural assumptions in standard reasoning on human information processing. Use of these insights is made in the practice of "behavioural pricing." 2 This practice may be used in the sales process. It involves adopting psychological insights to influence consumption, for instance by applying the insight that individuals use a mental accounting system to compare prices and value for money, assess affordability, etc. (Thaler 1999).

Here, some of the insights underlying "behavioural pricing" are mentioned.

Framing and Anchoring

First, there is the framing of price. For instance, the idea of description invariance holds that rational consumers should not be influenced by the way in which price is framed and presented. In practice, however, framing does matter. Consumer may be influenced by cloaking a surcharge for using credit card as a rebate for using cash, ${ }^{3}$ by disguising a lump sum as a small daily amount, or by charging $€ 14.99$ instead of $€ 15$. These pricing practices may elicit more demand than invariance theory would predict (Liu and Soman 2008). Likewise, there is framing through the use of promotion markers. These may be perceived as proxies for price cuts. Framing the cut can be relevant for the behavioural impact. A study into the differences in price perceptions when promotions were framed as either a price discount or a gift-with-purchase showed that consumers typically preferred the offprice promotion to the gift-with-purchase (Stanforth et al. 2001).

Secondly, there is anchoring. When the seller advertises the actual price on offer (also referred to as the advertised reference price, ARP) in comparison with other prices - usually the earlier selling price, the recommended retail price (RRP) or the competitor's price- he does so for reasons of promoting the product. By inserting a fictional retail price as a high anchor and adding the ARP as the reduced price, the seller might artificially boost demand. Indeed, research shows that the reservation price varies congruently with an irrelevant anchor (Kristensen and Gärling 2000). So, if sellers provide such an irrelevant anchor, they may influence consumption. If the comparison is factual incorrect or exaggerated, this will inflate perceived value of the bargain and may have adverse implications for competition (Office of Fair Trading 2005). The prohibition of the use of fictitious or irrelevant price cues to avoid decoy anchors seems a simple tool to prevent this.

\footnotetext{
${ }^{2}$ Furthermore, recent use of personal profiling in internet sales allows vendors to target consumers individually with specific offers that they might like - but it could also open opportunities to adjust pricing to consumer features and charge certain customers more than others simply because their buying profile shows aptitude for a low NCF (Office of Fair Trading 2010b). This further complication is not dealt with here.

${ }^{3}$ Indeed, there is some evidence that a rebate is perceived as more fair than a surcharge (Heyman and Mellers 2008; Kimes and Wirtz 2003).
} 
Comparison Incompetence

Thirdly, there is the issue of relative incompetence in comparing. As far as price comparison is concerned, studies have shown that framing a price comparison may elicit demand more effectively if framed as preventing an avoidable loss rather than if framed as a potential gain (Office of Fair Trading 2005). ${ }^{4}$ Other studies found that consumers are sensitive to the extent of the discount: higher discounts tend to increase propensity to buy, perceptions of quality and perceptions of value. Consumers were found to be most attracted to offers framed as a high discount from the RRP whereas strangely enough the least attractive offers were framed as high absolute savings (Office of Fair Trading 2005). In comparing prices, the bias of "relative thinking" has proved to be a more powerful motivator than absolute savings: a discount of $€ 5$ on a $€ 25$ object will increase demand more than a $€ 5$ saving on a $€ 500$ object (Thaler 1980). Consumer propensity for intuition (low NCF) may exacerbate this bias (Saini and Thota 2010).

\section{Advertising Items as "Gifts" or "For Free"}

Fourthly, there is the art of seduction through the use of cues such as "free," "gift," etc. Consumers are susceptible to such cues. Therefore, by bundling the focal product with a free gift, the vendor may cause an immediate short-term increase of demand for the product (although the long-term effects on customer retention and brand reputation are far from unambiguous; (Raghubir 2004)). However, the art of endowing with gifts is a subtle process - advertising a gift may be off-putting to high NCF consumers if the communication is too aggressive or not credible (Chandon and Chtourou 2005; Kamins et al. 2009; Office of Fair Trading 2010a).

\section{Bundling Items}

The fifth issue concerns the bundling of products. By bundling, a seller offers two or more products at a price which is different from the total price the consumer would pay when buying the products separately (Epstein 2006, p. 119). Bundles may avert attention from unit prices. If consumers have heterogeneous reservation prices for individual products, bundling products may increase the homogeneity of reservation prices and thus increase profitability $(1+1=3$; Hamilton and Srivastava 2008). Indeed, it seems that modern internet sales techniques enable sellers to relatively easily compose personal profiles of returning customers and on the basis of those profiles, structure the bundle to increase sales (Yang and Lai 2006).

\section{Locking-in the Consumer}

Related to bundling is the use of price variation and locking-in (also referred to as tying in): if consumers are drawn into long-term commercial relationships without proper knowledge of the fact that the price of future services may be unilaterally altered ("price variation") or without proper understanding of the additional, sequential, and unavoidable costs, they may find themselves locked in. Locking-in customers may happen when a product is offered without clearly communicating or drawing explicit attention to the additional costs that spare parts, maintenance, or accessories will impose on the consumer. For instance, by

\footnotetext{
${ }^{4}$ On loss aversion generally (Tversky and Kahneman 1986).
} 
presenting long-term service relationships as a single and one-off contracting decision on single goods may distort or artificially inflate demand. The profitability of such a strategy may depend on the proper functioning of the relevant market, on individual product demands, bundling costs, and the nature of the relationship between the demands of the products to be bundled (Bar-Gill 2006; Chakravarti et al. 2002; Janiszewski and Cunha 2004; McCardle et al. 2007). From the seller's point of view, obfuscating the price of future costs may be worthwhile. Consider the (average) cost of periodic servicing of motor vehicles: though a relevant price consideration, consumers are not actively informed of these costs. Once the motor vehicle is purchased, the consumer may be effectively locked in into a long-term relationship where price variation may reign. Locking-in may thus be especially worthwhile in experience goods which are infrequently bought (e.g., mortgages, life insurance).

Another good example of locking-in is the market for PC printers (Bar-Gill 2008). By keeping the purchase price of the printers low, manufacturers effectively lock in their customers because they can only purchase ink cartridges from the manufacturer (patents may protect the manufacturer from competitors offering cartridges at competitive prices) and they pay a high price for the ink cartridges during the life span of the printer. By using this concept, the profits made with the cartridges serve to cross-subsidize the artificially low price of the printer. The consumer may be unaware of this as he is typically not informed of the operational unit price per printed page. Therefore, he cannot compare the operational cost of printers. Instead, the consumer is drawn into a long-term relationship with the manufacturer by the advertised low printer price.

\section{Price Partitioning}

Finally, we need to consider the "price partitioning" technique. By partitioning, that is, cutting up the price in the sales sequence (basic price, options, surcharges, etc.), the consumer may be offered a false sense of autonomy. Thus, the illusion of free choice may be created. Likewise, offering additional services may elicit choice affect in consumers. This in turn may distract from the focus on price. Bundling products and services decreases the salience of individual components whereas partitioning the price may focus attention to one specific component. In essence, partitioning renders it more difficult for consumers to preliminarily assess and compare prices. As a consequence, it may increase demand and may cause the total price to look less expensive while implanting the original partitioned price in consumers' memory (Morwitz et al. 1998; Office of Fair Trading 2010a).

Consider for instance, research on partitioning unit price and shipping charges in online sales. First, for markets to operate efficiently, it is vital that additional costs are transparent. If price comparison is merely possible on the basis of advertised price while information on shipping costs, additional charges, etc., is withheld or obfuscated, the "cheapest" supplier may turn out to be the most expensive after all, if it turns out that he charges a ludicrous shipping and handling fee at the virtual check-out counter (Ellison and Fisher Ellison 2009). From this point of view, statutory provisions prescribing the use of all-inclusive prices or at least allowing comparison of total costs are preferable.

Theory would predict that as long as additional costs are transparent, the way in which the price is partitioned should not influence the demand for the product (principle of descriptive invariance): whichever way the supplier partitions the price, the consumer must pay for the total anyway. Empirical research, however, shows that the way the price is 
partitioned, does somehow influence demand. (Chakravarti et al. 2002; Tversky et al. 1988). For instance, low NFC consumers tend to pay less attention to surcharges in the sales process than high NFC consumers (Cheema 2008). The influence of partitioning is, however, not unambiguous. Some research suggests that partitioning has disparate effects for high and low NFC consumers (Kim and Kramer 2006; Morwitz et al. 1998). Some studies on the effectiveness of partitioned versus combined pricing show that for high NFC persons, partitioned pricing has a more favourable effect than combined pricing when the surcharges are reasonable; these effects reverse when the surcharges are unreasonable. The studies indicate no differences between partitioned and combined pricing across surcharge conditions for low NFC consumers (Burman and Biswas 2007). In other words, NFC consumers may display higher demand for products sold with a partitioned price if the surcharge is reasonable. If it is not, suppliers are well advised not to partition.

Another method of partitioning is by framing a unit price in "pennies-a-day:" by showing how much a product effectively costs per day (temporal partitioning) the seller systematically fosters the retrieval and consideration of small ongoing expenses as the standard of comparison, whereas an aggregate framing of that same transaction is shown to foster the retrieval and consideration of large and infrequent expenses. This difference in retrieval is shown to significantly influence subsequent transaction evaluation and compliance (Gourville 1998). Another study showed that consumers prefer partitions that allocate a larger proportion of the total price to components perceived as providing high benefits to partitions that allocate a larger proportion of the total price to components perceived as providing low benefits (Hamilton and Srivastava 2008). The technique of making consumers focus on the "pennies-a-day" price is well-known in consumer credit. If left unregulated, lenders have shown to obfuscate the price of credit by stressing the amount of monthly instalments rather than the overall interest (cf. Bertrand and Morse 2009; White 2007). This technique helps to frame the proposition favourably and to anchor the borrower's thinking - rather than considering the total amount in interest he might focus on the periodic payments and their consistency with his budgetary constraints.

\section{The European Legal Framework}

In the previous section, I considered some means of influencing perceptions and valuations of price. The way in which price is framed, stimulating certain anchors, exploiting the inability to compare, cueing through the use of words such as "free gift," clever use of bundling and locking-in mechanisms, as well as price partitioning, are just some of the commercial practices used to influence the consumer decision-making process and to boost demand. The question is: are these practices legitimate ways of promoting sales or do they significantly distort the consumer decision-making process so as to justify legislative intervention? Surely not all means of influencing consumer thinking and deciding by fogging over their vision warrant legislative intervention. A certain level of intransparency and obfuscation will have to be tolerated and will be eradicated by the market itself. ${ }^{5}$ Furthermore, in some markets, dubious pricing practices are somehow accepted as part and parcel of that particular market. For instance, consumer

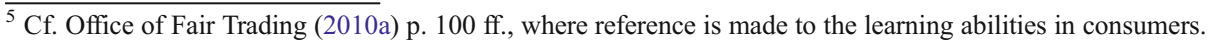


habituation to price obfuscation may decrease the distortive effects of such unfair practices. Nowadays, high NCF consumers would be nothing less than utterly vigilant not to be tricked when booking with certain budget airlines. That said, the more subtle and misleading an obfuscatory practice may be, the louder the call for regulatory intervention may be.

Hence, a closer look at the regulatory framework for evaluating price transparency currently in force in European consumer law is appropriate. This framework consists of two parts. On the one hand, there are concrete rule-based provisions on price which are mainly to be found in the 1998 Unit Prices Directive. ${ }^{6}$ On the other hand, there are principle-based duties which are mainly to be found in the 2005 Unfair Commercial Practices Directive, ${ }^{7}$ and the 2008 Draft Consumer Rights Directive. ${ }^{8}$ Together, these European rules make up the regulatory framework for judging price transparency. The question here is whether and to what extent the European legal framework addresses the implications of the existing practices by which vendors attempt to influence perceptions and valuations of price. In dealing with this question, I will briefly refer to some national case law - notably German case law - to illustrate the judicial application of the rules laid down in the aforementioned Directives. ${ }^{9}$ The review of case law is by no means exhaustive but merely illustrative.

\section{Specific Rules on Pricing}

The 1998 Unit Prices Directive is based on the notion of price transparency through the establishment of common principles for indicating prices. This is considered to be the easiest way to enable consumers to evaluate and compare the price of products in an optimal manner and make informed choices on the basis of simple comparisons (preamble; recital 6; art. 1). The Directive sets forth the following basic rules for retail sales:

- Products should be offered with a selling price (the final price for a unit or a given quantity of the product, including VAT and all other taxes).

- Where applicable a unit price (the final price, including VAT and all other taxes, for $1 \mathrm{kh}, 11,1 \mathrm{~m}$, etc.) should be communicated unless unit price and selling price are identical.

- The selling price and the unit price must be unambiguous, easily identifiable and clearly legible.

Though non-compliance with these information requirements is considered an unfair commercial practice, ${ }^{10}$ the scope of these requirements is quite narrow. Moreover, the Directive is of a minimum harmonization character and allows Member States to exempt certain products. For instance, the obligation to display the unit price may be waived if

\footnotetext{
${ }^{6}$ Directive 98/6/EC of the European Parliament and of the Council of 16 February 1998 on consumer protection in the indication of the prices of products offered to consumers (OJ L 080/27).

${ }^{7}$ Directive 2005/29/EC of 11 May 2005 (OJ L 149/22) (Unfair Commercial Practices Directive). See also art. 22 Services Directive (Directive 2006/123/EC of 12 December 2006 on services in the internal market, OJ L 376/36). Art. 22 sets forth the duty to give unambiguous and timely information on the price or the calculation method used to determine the price.

${ }^{8}$ Proposal for a Directive of the European Parliament and of the Council on Consumer Rights, COM(2008) 614 final.

${ }^{9}$ For further examples predating the 2005 UCP Directive, see Schulze and Schulte-Nölke (2003).

${ }^{10}$ Article 7 (5) and Annex II of the 2005 UCP Directive.
} 
the Member State considers it impractical or confusing. ${ }^{11}$ In case law, the following practices have been considered contrary to the Unit Prices Directive: putting discounted products on offer as " $20 \%$ off" without displaying the final selling price, ${ }^{12}$ advertising soft drinks for sale in a deposit bottle without mention of the deposit, ${ }^{13}$ advertising kitchen towels with a unit price per kilogramme. ${ }^{14}$

Given their basic and straightforward nature, the transparency requirements under the 1998 Unit Prices Directive do not explicitly tackle all transparency issues such as bundling or locking-in. The Directive effectively orders supermarkets to display the price of, say, apples per kilogramme (the unit price) while there is no such mechanism to guarantee "per unit" transparency in lock-in bundles (e.g., expected price per printed page in printers rather than the "unit" of the printer itself).

Moreover, the 1998 Unit Prices Directive does not seem to prevent persistent practices of so-called partitioning of prices. Some of these practices were so persistent that policymakers at EU level enacted specific regulation to address the detrimental effects caused by these practices. A case in point is the online sale of budget airline tickets. For some time, the partitioning technique was popular in online air flight tickets. To counter the obfuscatory practices, specific rules on pricing transparency in air travel services were promulgated in 2008. Currently, article 23 of the Air Services Regulation 1008/2008 provides that the final price shall include "unavoidable and foreseeable" fees, taxes, etc. ${ }^{15}$ Furthermore, optional price supplements are to be "communicated in a clear, transparent and unambiguous way at the start of any booking process and their acceptance by the customer shall be on an 'opt-in' basis." A crucial addition in article 23 is that the final price to be paid "shall at all times be indicated." This is an important step towards true transparency because the 1998 Unit Prices Directive does not prohibit the sequential partitioning of the final price by drawing consumers with a basic price while adding on unavoidable and foreseeable charges at a later stage in the online sales sequence. The Air Services Regulation does in fact address the partitioning issue and one could consider whether perhaps this particular element of article 23 merits broader application to all $\mathrm{B} 2 \mathrm{C}$ transactions.

\section{The UCP Directive and Price Transparency}

The principle-based framework of the 2005 Unfair Commercial Practices (UCP) Directive seems more encompassing then the specific rules analysed above. However, the UCP Directive aims at full harmonization and leaves little room to Member States to promulgate specific rules on price transparency. ${ }^{16}$ As we will see later on, this may hamper rather than promote consumer protection. In fact, implementation of the UCP Directive necessitated Member States to repeal much of their specific domestic rules on pricing information (Howells et al. 2006). Some Member States had to repeal regulations on compulsory price displays for hair salons, others had to do away with rules on mandatory lists of at least 30

\footnotetext{
${ }^{11}$ Article 5 of the 1998 Unit Prices Directive. A list of national exceptions is to be found at EIM Business and Policy Research (2004) 137.

12 BGH 25 February 1999, Case I ZR 4/97, GRUR 1999, p. 762 ("Herabgesetzte Schlussverkaufspreise"); for a similar decision, see BGH 11 April 1991, Case I ZR 166/89, GRUR 1991, 685 ("Zirka-Preisangabe").

${ }_{13}$ BGH 14 October 1993, Case I ZR 218/91, GRUR 1994, 222 ("Flaschenpfand").

${ }^{14}$ BGH 21 May 1992, Case I ZR 141/90, GRUR 1992, 856 (“Kilopreise IV”).

${ }^{15}$ Cf. BGH 17 October 1980, Case I ZR 132/78, GRUR 1981, 140 ("Flughafengebühr").

${ }^{16}$ E.g., the English Consumer Protection (Code of Practice for Traders on Price Indications) Approval Order 2005 may be in conflict in certain respects with the full harmonization character of the 2005 UCP Directive.
} 
different drinks in pubs (cf. Williams and Hare 2010, p. 383 fn 12). So, in some Member States the 2005 UCP Directive has relaxed existing price transparency regimes instead of tightening them.

First, let us have a closer look at the 2005 UCP regime. The Directive is applicable to unfair commercial practices, i.e., those practices contrary to the requirements of professional diligence which materially distort or are likely to materially distort the economic behaviour of the average (targeted) consumer with regard to the product (article 5). The concept of "unfair" is further subcategorized into misleading and aggressive practices. Misleading practices are those which either

(1) contain false information and are therefore untruthful or in any way deceive or are likely to deceive the average consumer, even if the information is factually correct, which thus cause distortion of the transactional decision-making process of this average consumer in relation to certain aspects such as, e.g., the existence or nature of the product, fitness for purpose, usage, quantity, specification, the price or the manner in which the price is calculated, the need for a service, part, replacement or repair, etc. (article 6 (1)),

or

(2) omit, hide, provide in an unclear, unintelligible, ambiguous, or untimely manner material information that the average (targeted) consumer needs, according to the context, to take an informed transactional decision and thus cause distortion of the transactional decision-making process of this average consumer (article 7).

Furthermore, Annex I to the Directive consists of a "black list" of certain practices deemed unfair under any circumstances (article 5 (5)). For instance, outright unfair is a commercial practice "describing a product as 'gratis', 'free', 'without charge' or similar, if the consumer has to pay anything other than the unavoidable cost of responding to the commercial practice and collecting or paying for delivery of the item" (Annex I, no. 20). ${ }^{17}$

Moreover, the UCP Directive provides that in a so-called "invitation to purchase" (which basically is a retail offer comprising basic information on the product and price), the price information should be presented as "the price inclusive of taxes, or where the nature of the product means that the price cannot reasonably be calculated in advance, the manner in which the price is calculated, as well as, where appropriate, all additional freight, delivery or postal charges or, where these charges cannot reasonably be calculated in advance, the fact that such additional charges may be payable."18

What are the consequences of the UCP regime for pricing transparency? The short and easy answer is that information on price shall be truthful and non-misleading, thus allowing the average consumer to make an informed transactional decision. However, the more extensive answer is rather more complex.

\section{Vulnerable Consumers and "Easy Cases" under the UCP Directive}

First, one should look whether the product is targeted at a particular group of consumers. When a commercial practice is specifically aimed at a particular group of consumers, such

\footnotetext{
${ }^{17}$ For other examples, see, e.g., Ramsay (2007) p. 313.

${ }^{18}$ Cf. art. 5 (1) (c) Draft Consumer Rights Directive (COM (2008) 614 final). Note that the art. 22 (3) (a) Services Directive $(2006 / 123 / \mathrm{EC})$ gives a slightly different wording by obliging the service provider to supply, at the recipient's request, "where the price is not pre-determined by the provider for a given type of service, the price of the service or, if an exact price cannot be given, the method for calculating the price so that it can be checked by the recipient, or a sufficiently detailed estimate."
} 
as children, it is desirable that the impact of the commercial practice is assessed from the perspective of the average member of that group (recital 18). So, if a trader avails himself of a glossy advertising leaflet to entice young girls to enter the "Pony Club" - that is, a longterm subscription to a periodical - and the front of the leaflet states the price of the "welcome pack" but the (higher) price of subsequent dispatches is only mentioned in the small print on the back of the subscription form, then a court may hold that this way of marketing a product is unfair as it withholds easily accessible price information. ${ }^{19}$

Then, there are the "easy" cases. Generally, the UCP framework prohibits the use of incorrect or exaggerated comparison prices as misleading (e.g., illusionary RRP). ${ }^{20}$ Bogus cues-for instance, advertising a price as "slashed" while it isn't (e.g., summer sales reduced prices turning out to be identical to just before or after the sales period) - are misleading as well. ${ }^{21}$ Similarly, raising the price of the entire range of products on offer just before displaying " $20 \%$ off all products" will probably also count as unfair. ${ }^{22}$

\section{Behavioural Pricing and the Average Consumer}

Rather more difficult to assess is the matter of influencing the average consumer by subtly obfuscating price. ${ }^{23}$ If information on price is made available to the consumer but in a somewhat concealed way, how would that affect the average consumer? In the "Pony Club" example, imagine that this sales technique is used in a product marketed for the general adult population. Would that count as a case of unfair obfuscation of price? On the one hand, the "reasonably well informed and reasonably observant and circumspect" consumer can be expected to make a serious effort at collecting and understanding all available information on an essential aspect such as price. ${ }^{24}$ On the other hand, the UCP framework aims at giving traders an incentive to give price information in a clear, intelligible, unambiguous, and timely fashion. The tenure of the UCP Directive seems to be that whether a given technique of price obfuscation is actually an unfair commercial practice must be decided from case to case by national courts and enforcers (with some level of overlooking by the ECJ). There is however little room for national legislatures to make their own "black list" of unfair pricing practices by fully and generally banning these practices. So, a national list stating that "promotional material shall always mention the price of subscription on the front" would run counter to the full harmonization nature of the Directive. For this reason, the ECJ is keen on stamping out the use of additional national "black lists." 25

\footnotetext{
${ }_{19}$ Austrian Oberster Gerichtshof (OGH) 8 July 2008 (file 4Ob57/08y).

${ }^{20}$ European Commission (2009) 34.

${ }^{21}$ E.g., Collins (2005) p. 422 ; Köhler and Bornkamm (2010) para 5, no. 6.5.

${ }^{22}$ OFT v The Officers Club Limited and David Charlton [2005] EWHC 1080 (Ch.) (“70\% off”); BGH 20 November 2008, Case I ZR 122/06, GRUR 2009, p. 788 (“20\% auf alles"). Cf. Ramsay (2007) p. 315 ff.

${ }^{23}$ On the concept of "average consumer" and how to identify him, see, e.g., European Commission, Guidance on the Implementation/Application of Directive 2005/29/EC on Unfair Commercial Practices (SEC (2009)1666), Brussels: European Commission (2009) pp. 27-28, pp. 32-33; Willett (2010) pp. 269-271; Gomez (2006) pp. 26-27; Weatherill (2006) p. $115 \mathrm{ff}$.

${ }^{24}$ ECJ 16 July 1998, C-210/96 (Gut Springenheide); ECJ 19 September 2006, C-356/04 (Lidl and Colruyt); cf. ECJ 6 July 1995, C-470/93, Jur. 1995 p. I-01923 (Mars).

${ }^{25}$ ECJ April 23, 2009, cases C-261/07 and C-299/07 (VTB-VAB NV v. Total Belgium NV/Galatea BVBAv. Sanoma Magazines Belgium NV): national legislation which prohibits the bundling of products by "combined offer," without taking account of the specific circumstances, is inconsistent with the UCP Directive. Cf. ECJ March, 11, 2010, case C-522/08 (Telekomunikacja Polska SA w Warszawie v. Prezes Urzędu Komunikacji Elektronicznej).
} 
Is Causing Price Intransparency through Bundling a UCP?

This raises the question to what extent the more sophisticated methods of price obfuscation, such as bundling and partitioning, are prohibited under the UCP framework. Is bundling a free product with another product allowed? Though in principle the answer is affirmative, such an offer may sometimes amount to an unfair commercial practice. "Describing a product as 'gratis', 'free', 'without charge' or similar if the consumer has to pay anything other than the unavoidable cost of responding to the commercial practice and collecting or paying for delivery of the item" is deemed unfair (Annex I, no. 20). Though clear at first glance, at a closer look this prohibition is rather problematic. It seems only to relate to stand-alone offers and not to affect the bundling of multiple products of which one is free. Nor does it seem to apply to offers such as "buy one get one free" or " 3 for 2 ." Hence, the ambit of this prohibition is rather limited. It does not seem to have any relevance in cases in which a product is advertised for " $€ 0.00$ *" where the asterisk refers to small print or where small printed statements such as "terms and conditions apply" is used. If it were to apply to those practices, some sales methods would be rendered illegal-for instance used in advertising long term mobile telephone contracts by luring customers with a "free" mobile phone. It seems that such practices are not covered by Annex I, no. 20. Likewise, offering a bonus with a purchase may not be generally prohibited by Member States: a national provision which lays down a general prohibition on sales with bonuses is inconsistent with the full harmonization character of the UCP Directive. ${ }^{26}$ For the same reason, seducing consumers by offering a free participation in a lottery if they purchase some product, may not be outright prohibited. ${ }^{27}$

Bundling with "free" items may nevertheless amount to a misleading practice in concrete cases if the actual price is not provided in a clear, intelligible, and unambiguous or timely manner. For instance, in German case law, the practice of advertising a mobile telephone tariff on a large billboard at " 0.00 monthly fee*" where the asterisk referred to small print stating a considerable contract fee, minimum number of monthly calls, minimum contract running period, was considered an intransparent pricing technique that added up to an unfair commercial practice. ${ }^{28}$ One could also look at it from another angle by stating, as does Section 4 (4) of the German Gesetz gegen den unlauteren Wettbewerb (UWG), that a person acts unfair if he "does not clearly and unambiguously communicate the applicable conditions of sales promotions such as rebates, premiums or free gifts." 29 Therefore, one could conclude that the conditions of the bundle should be communicated clearly and unambiguously.

So, bundling as such is not forbidden by the UCP framework as long as the total price is transparent. The UCP Directive does not oblige the trader to disclose the value of the singular units in the bundle. So, a general national rule on mandatory disclosure of unit

\footnotetext{
${ }^{26}$ ECJ November 9, 2010, case C 540/08 (Mediaprint Zeitungs- und Zeitschriftenverlag GmbH \& Co. KG v. 'Österreich'-Zeitungsverlag $\mathrm{GmbH}$ ).

${ }^{27}$ ECJ January 14, 2010, case C-304/08 (Zentrale zur Bekämpfung unlauteren Wettbewerbs e.V. v. Plus Warenhandelsgesellschaft $\mathrm{GmbH})$.

${ }^{28}$ BGH 22 April 2009, Case I ZR 14/07 (“0,00 Grundgebüh”). A similar high level of transparency was required according to BGH 17 July 2008, Case I ZR 139/05, GRUR 2009, p. 73 (“Telefonieren für 0 Cent!”). Moreover, if the reference omits to mention material price information, the advertised price is misleading a fortiori: BGH 2 June 2005, Case I ZR 252/02, GRUR 2006, p. 164 (Aktivierungskosten II).

${ }^{29}$ See Keirsbilck (2009) 522 for the question whether the German UWG is in conformity with the maximum harmonisation character of the UCP Directive.
} 
prices in a bundled offer would seem contrary to the UCP framework. Yet, German case law holds that if the bundle interferes with the consumer's perception in the sense that it confuses or insufficiently informs him of the price of the actual offer, the trader is under the duty to inform the consumer transparently. ${ }^{30}$

\section{Is Partitioning Price a UCP?}

The UCP Directive is not really clear on the extent to which partitioning of price is allowed. In invitations to purchase the price information is to be presented as "the price inclusive of taxes (...) as well as, where appropriate, all additional freight, delivery or postal charges (...)" (article 7 (4) (c)). This does not explicitly deal with the issue of "chopping up" the price in sequential parts in the sales process. Obviously, in some cases traders have a clear and justified interest in partitioning. For instance, partitioning the price of a holiday home into a fixed rent and variable charges for utilities may be fully justified under the condition that the partitions are clearly communicated. ${ }^{31}$ In other cases, though, the justification for partitioning may be completely absent. The practice of chopping up the price as currently dealt with in the Air Services Regulation $1008 / 2008$ is persistent in other markets as well. So, is an internet shop still allowed to advertise a PC as costing $€ 499$ while adding a further $€ 50$ in "handling costs" during the sales process? Neither the UCP Directive nor the Unit Prices Directive addresses this issue - therefore, it will depend on the specifics of a given case whether such partitioning can be considered presenting price information in an unclear, unintelligible, ambiguous or untimely manner.

Somewhat similar to partitioning is the practice of using pre-ticked boxes which consumers have to untick to avoid adding on secondary services to the primary product. Article 31 (3) of the Draft Directive on Consumer Rights ("Transparency requirements of contract terms") combats pre-ticked boxes by providing: "The trader shall seek the express consent of the consumer to any payment in addition to the remuneration foreseen for the trader's main contractual obligation. If the trader has not obtained the consumer's express consent but has inferred it by using default options which the consumer is required to reject in order to avoid the additional payment, the consumer shall be entitled to reimbursement of this payment." Obviously, article 31 does not apply to those options that cannot be unticked so it does not deal with the practice of first partitioning price and then adding unavoidable charges in the sequence of the selling process. What it may positively deal with, though, is inflated sales of add-on insurance, warranty extensions, super delivery charges, etc. In offline retail, the sale of such add-on products can develop worrying proportions. A case in point concerns add-on insurance policies which are offered as a secondary product with credit card loans, consumer electronics and cell phones. The marketing technique employed to sell add-on insurance in consumer electronics for instance is rather sophisticated: as soon as the consumer has decided to buy the product, he is offered the opportunity to buy additional insurance to protect his newly acquired property. ${ }^{32}$ Given that he has just been endowed with property, he may then not be able to objectively weigh the premium cost against the probability of loss. This may in

\footnotetext{
${ }^{30}$ BGH 13 June 2002, Case I ZR 173/01, GRUR 2002, p. 976, BGHZ 151, p. 84 (Koppelungsangebot I); BGH 13 June 2002, Case I ZR 71/01, GRUR 2002, 979 (Koppelungsangebot II).

${ }^{31}$ BGH 6 June 1991, Case I ZR 291/89, GRUR 1991, 845 ("Nebenkosten Ferienwohnung").

32 Similar techniques are applied in the sale of extended warranties in consumer products.
} 
fact influence his willingness to avoid the loss and it may even influence the insured's willingness to obtain additional information on the terms of the contract (either at the counter or afterwards if a termination clause or cooling-off period applies). Admittedly, the proposition of these causative mechanisms is speculative and deserves empirical investigation but the research that is available does show that the claims/premium ratio in some of these add-on insurance policies may be hugely disadvantageous for consumers. This implies that there is a structural market failure in operation in these particular markets (Van Boom 2008). ${ }^{33}$

Perhaps a similar mechanism is in operation in online sales by use of pre-ticked boxes that pop up at the virtual check-out counter - though the pressure and persuasion applied by salesmen in the face-to-face offline buying experience will be more substantial than in an online equivalent. In this respect, by forbidding pre-ticked boxes policymakers may help to prevent the artificially inflated sales of add-on products. If the trader wants an additional remuneration beside the primary price, the Draft Consumer Rights Directive demands that explicit consent is obtained from the buyer. ${ }^{34}$

Undoubtedly, there are numerous sales techniques available to circumvent the prohibition of pre-ticked boxes as proposed by the Draft Consumer Rights Directive (EC 2008). What if the trader raises the price and offers a rebate if the add-on products are bought? And what if certain boxes cannot be unticked? If a trader offers a holiday accommodation rental only in combination with a liability insurance, does article 31 (4) prohibit the partitioning of this unavoidable extra cost from the rent itself? If that is indeed the consequence of article 31, it might lead to less transparency in the sense that it induces traders to merely present the total price rather than the price of the modules that build up the product. Therefore, it remains to be seen whether and to what extent article 31 -assuming it will be part of the final Directive - will indeed lead to the desired result of safeguarding explicit consent and thus increasing consumer autonomy.

\section{Appraisal}

In this article, I reviewed behavioural sciences research to chart some of the influences of price intransparency on the consumer decision-making process. Next, I analysed how the European legal framework responds to some practices of price intransparency. It emerged that European consumer law seems to address the more straightforward misleading pricing practices - such as using a fictitious anchor price-but fails to explicitly address the more subtle obfuscatory practices that are implied in certain bundling practices and certain price partitioning techniques. The question is whether such practices warrant legislative intervention. From the outset, it does not seem appropriate to prohibit all forms of bundling and partitioning as such. Some markets, however, may be more problematic than others. For example, policymakers at the European level considered the online sales techniques of some budget airlines so disruptive as to warrant intervention in pricing practices. This leads me to reflect further on the relationship between the notion of "average consumer," the increasing full

\footnotetext{
33 OFT (1997) p. 1 ff. Possibly, one of the causes for this unbalance is a combination of information asymmetry on the actual need for such insurance and the "endowment effect" on the side of the insured. Note that the endowment effect and its extent are debated. See, e.g., Zeiler and Plott (2005) p. $530 \mathrm{ff}$.

${ }^{34}$ EC (2008) pp. 17-18, recital no. 47.
} 
harmonization character of European consumer law and the combat of specific practices of price intransparency deemed unfair at Member State level.

It seems there is a tension between insights from behavioural science and the normative concept of the average consumer, given the full harmonization principle of the UCP Directive. The normative notion of "average consumer" makes it unlikely that judicial and legislative efforts will be devoted to researching how consumers actually think and decide and perceive price information (Incardona and Poncibò 2007). However, the growing body of empirical research does offer invaluable insights in actual thinking and deciding concerning price. This line of research analyses the influence of the way in which price is framed, how sales techniques can stimulate certain anchors, exploit the inability to compare, give subliminal cues through the use of words such as "free gift," how clever use of bundling and locking-in mechanisms as well as price partitioning may influence the consumer decision-making process. In doing so, researchers at times distinguish between high and low NCF consumers and they find diverging decision-making strategies in these two "types" of the "average consumer."

The insights from empirical research can be used by national courts and enforcement agencies to fine tune the use of legal instruments already available in European consumer law. Though empirical research can hardly substitute the normative concept of "average consumer," it can help to identify and address the cognitive fallacies that consumers may fall prey to, and that distort their market behaviour. Price transparency is important for markets to function. Both the 1998 Unit Prices Directive and the 2005 UCP Directive lay down rules on transparency and to some extent they tackle clear cases of obfuscation - for instance, comparisons with untruthful RRP's and decoy cues are prohibited. More complex sales techniques such as the partitioning of price and bundling of offers are not dealt with in a straightforward way. Courts and national enforcement authorities are to judge every case on its own merits and decide whether the pricing technique used is a misleading commercial practice in the given circumstances. National legislatures are not allowed to outright ban such techniques without having regard for the particular situation in which the technique is applied. All in all, this seems a correct approach. Subtle sales techniques as such cannot be considered contrary to the requirements of professional diligence under all circumstances - $a$ flexible approach is therefore in order. The drawback of this approach is undoubtedly that the hands of national policymakers are tied when it comes to combating specific sales techniques in specific areas. If policymakers in country $\mathrm{X}$ would feel that the widespread practice of partitioning price in a specific market is detrimental to consumer confidence in that specific market, they would nevertheless lack the powers to ban that particular practice, or so it seems.

A similar problem arises when we look at pricing regulations aimed at giving consumers a better understanding of the long-term implications of their purchase. It seems that the full harmonization character of the UCP Directive is not easily reconciled with regulations on "meaningful pricing," for instance regulations that would order suppliers of home printers to advertise an "average price per printed page" rather than merely the unit price of the printer itself. Perfect price transparency allows comparing offers of multiple suppliers. Hence, transparency amounts to more than mere calculus. It must be meaningful transparency. If indeed the full harmonization character of the UCP Directive does not allow the development of such rules on "meaningful price transparency," then perhaps the UCP Directive stifles rather than fosters innovation in the context of consumer empowerment. 
Open Access This article is distributed under the terms of the Creative Commons Attribution Noncommercial License which permits any noncommercial use, distribution, and reproduction in any medium, provided the original author(s) and source are credited.

\section{References}

Bar-Gill, O. (2006). Bundling and consumer misperception. University of Chicago Law Review, 73, 33-61. Bar-Gill, O. (2008). The behavioral economics of consumer contracts. Minnesota Law Review, 92, 749-802. Bertrand, M., \& Morse, A. (2009). Information disclosure, cognitive biases and payday borrowing. Chicago: Milton Friedman Institute-University of Chicago.

Bettman, J. R., Luce, M. F., \& Payne, J. W. (1998). Constructive consumer choice processes. Journal of Consumer Research, 25(3), 187-217.

Burman, B., \& Biswas, A. (2007). Partitioned pricing: Can we always divide and prosper? Journal of Retailing, 83(4), 423-436.

Carlin, B. I. (2009). Strategic price complexity in retail financial markets. Journal of Financial Economics, 91(3), 278-287.

Chakravarti, D., Krish, R., Paul, P., \& Srivastava, J. (2002). Partitioned presentation of multicomponent bundle prices: Evaluation, choice and underlying processing effects. Journal of Consumer Psychology, 12(3), 215-229.

Chandon, J.-L., \& Chtourou, M. S. (2005). Factors affecting click-through rate. In C. P. Haugtvedt, K. A. Machleit, \& R. F. Yalch (Eds.), Online consumer psychology: Understanding and influencing consumer behavior in the virtual world (pp. 143-165). New Jersey: LEA.

Cheema, A. (2008). Surcharges and seller reputation. Journal of Consumer Research, 35(1), 167-177.

Chen, T., Kalra, A., \& Sun, B. (2009). Why do consumers buy extended service contracts? Journal of Consumer Research, 36(4), 611-623.

Collins, H. (2005). The unfair commercial practices directive. ECLR, 4, 417-440.

Commission, E. (2009). Guidance on the implementation/application of Directive 2005/29/EC on unfair commercial practices (sec (2009) 1666). Brussels: European Commission.

EC. (2008). Proposal for a directive of the european parliament and of the council (No. COM(2008)614/3). Brussels: European Commission.

EIM Business \& Policy Research. (2004). Appraisal of directive 98/6/EC on consumer protection in the indication of unit prices of products offered to consumers-Final report. Zoetermeer: EIM Business \& Policy Research.

Ellison, G., \& Fisher Ellison, S. (2009). Search, obfuscation, and price elasticities on the internet. Econometrica, 77(2), 427-452.

Epstein, R. A. (2006). Behavioral economics: Human errors and market corrections. University of Chicago Law Review, 73, 111-132.

Gomez, F. (2006). The unfair commercial practices directive: A law and economics perspective. European Review of Contract Law, 1, 4-34.

Gourville, J. T. (1998). Pennies-a-day: The effect of temporal reframing on transaction evaluation. Journal of Consumer Research, 24(4), 395-403.

Hamilton, R. W., \& Srivastava, J. (2008). When $2+2$ is not the same as $1+3$ : Variations in price sensitivity across components of partitioned prices. Journal of Marketing Research, 45(4).

Hanf, C. H., \& von Wersebe, B. (1994). Price, quality, and consumers' behaviour. Journal of Consumer Policy, 17, 335-348.

Henry, P. (2005). Is the internet empowering consumers to make better decisions, or strengthening marketers' potential to persuade? In C. P. Haugtvedt, K. A. Machleit, \& R. F. Yalch (Eds.), Online consumer psychology: Understanding and influencing consumer behavior in the virtual world (pp. 345-360). New Jersey: LEA.

Heyman, J. E., \& Mellers, M. A. (2008). Perceptions of fair pricing. In C. P. Haugtvedt, P. M. Herr, \& F. R. Kardes (Eds.), Handbook of consumer psychology (pp. 683-697). New York: Psychology Press.

Howells, G. G., Micklitz, H.-W., \& Wilhelmsson, T. (2006). European fair trading law; The unfair commercial practices directive. Aldershot: Ashgate.

Incardona, R., \& Poncibò, C. (2007). The average consumer, the unfair commercial practices directive, and the cognitive revolution. Journal of Consumer Policy, 30, 21-38.

Inman, J. J., \& McAlister, L. (1993). A retailer promotion policy model considering promotion signal sensitivity. Marketing Science, 12(4), 339-356. 
Inman, J. J., McAlister, L., \& Hoyer, W. D. (1990). Promotion signal: Proxy for a price cut? Journal of Consumer Research: An Interdisciplinary Quarterly, 17, 74-81.

Janiszewski, C., \& Cunha, M. (2004). The influence of price discount framing on the evaluation of a product bundle. Journal of Consumer Research, 30, 534-546.

Kamins, M., Folkes, V., \& Fedorikhin, A. (2009). Promotional bundles and consumers' price judgments: When the best things in life are not free. Journal of Consumer Research, 36, 660-670.

Keirsbilck, B. (2009). Towards a single regulatory framework on unfair commercial practices? EBLR, 507564

Kim, H., \& Kramer, T. (2006). The moderating effects of need for cognition and cognitive effort on responses to multi-dimensional prices. Marketing Letters, 17(3), 193-203.

Kimes, S. E., \& Wirtz, J. (2003). Perceived fairness of revenue management in the US golf industry. Journal of Revenue and Pricing Management, 1, 332-344.

Kirchler, E., Fischer, F., \& Hölzl, E. (2010). Price and its relation to objective and subjective product quality: Evidence from the austrian market. Journal of Consumer Policy, 31, 139-145.

Köhler, H., \& Bornkamm, J. (2010). Gesetz gegen den unlauteren wettbewerb (Beck Kurz-Kommentare Bd 13a). München: Beck.

Kristensen, H., \& Gärling, T. (2000). Anchoring induced biases in consumer price negotiations. Journal of Consumer Policy, 23, 445-460.

Liu, M. W., \& Soman, D. (2008). Behavioral pricing. In C. P. Haugtvedt, P. M. Herr, \& F. R. Kardes (Eds.), Handbook of Consumer Psychology (pp. 659-681). New York: Psychology Press.

Markman, A. B., \& Loewenstein, J. (2010). Structural comparison and consumer choice. Journal of Consumer Psychology, 20, 126-137.

McCardle, K. F., Rajaram, K., \& Tang, C. S. (2007). Bundling retail products: Models and analysis. European Journal of Operational Research, 177(2), 1197-1217.

Morwitz, V. G., Greenleaf, E. A., \& Johnson, E. J. (1998). Divide and prosper: Consumers' reactions to partitioned prices. Journal of Marketing Research, 35, 453-463.

Office of Fair Trading. (2005). Research into misleading price comparisons-prepared for the OFT by Nottingham University Business School (OFT790). London: OFT.

Office of Fair Trading. (2010a). Advertising of prices (OFT 1291). London: OFT.

Office of Fair Trading. (2010b). Online targeting of advertising and pricing-A market study (OFT1231). London: OFT.

OFT (1997). Consumer detriment under conditions of imperfect information (prepared for the office of fair trading by london economics) (No. Research Paper 11). London: Office of Fair Trading (OFT)

Raghubir, P. (2004). Free gift with purchase: Promoting or discounting the brand? Journal of Consumer Psychology, 14(1\&2), 181-186.

Ramsay, I. (2007). Consumer law and policy: Text and materials on regulating consumer markets (2nd ed.). Oxford; Portland, Or: Hart.

Saini, R., \& Thota, S. C. (2010). The psychological underpinnings of relative thinking in price comparisons. Journal of Consumer Psychology, 20, 185-192.

Schulze, R., \& Schulte-Nölke, H. (2003). Analysis of national fairness laws aimed at protecting consumers in relation to commercial practices.

Schwartz, B. (2004). The paradox of choice: Why more is less (1st ed.). New York: Ecco.

Simon, H. A. (1955). A behavioral model of rational choice. Quarterly Journal of Economics, 69(1), 99-118.

Stanforth, N., Lennon, S., \& Shin, J. I. (2001). Promotional frames' influence on price perceptions of two apparel products. Family and Consumer Sciences Research Journal, 30, 79-92.

Sutton, R., \& Riesz, P. (1979). The effect of product visibility upon the relationship between price and quality. Journal of Consumer Policy, 3, 145-150.

Thaler, R. H. (1980). Towards a positive theory of consumer choice. Journal of Economic Behavior and Organization, 1, 39-60.

Thaler, R. H. (1999). Mental accounting matters. Behavioral Decision Making, 12, 183-206.

Tversky, A., \& Kahneman, D. (1986). Rational choice and the framing of decisions. Journal of Business, 59 (4), 251-278.

Tversky, A., Sattath, S., \& Slovic, P. (1988). Contingent weighting in judgment and choice. Psychological Review, 95(3), 371-384.

Van Boom, W. H. (2008). Insurance law and economics: An empirical perspective. In M. Faure \& F. Stephen (Eds.), Essays in the law and economics of regulation-In honour of Anthony Ogus (pp. 253-276). Antwerp/Oxford/Portland: Intersentia.

Weatherill, S. (2006). Who is the 'average consumer'? In S. Weatherill \& U. Bernitz (Eds.), The Regulation of unfair commercial practices under EC directive 2005/29; New rules and new techniques (pp. 115-138). Oxford: Hart Publishing. 
White, A. (2007). Behavior and Contract. Valparaiso University School of Law Legal Studies Research Paper Series.

Willett, C. (2010). Fairness and consumer decision making under the unfair commercial practices directive. Journal of Consumer Policy, 33, 247-273.

Williams, J., \& Hare, C. (2010). Early experiences of the enforcement of the unfair commercial practices directive in Scotland. Journal of Consumer Policy, 33, 377-401.

Yang, T.-C., \& Lai, H. (2006). Comparison of product bundling strategies on different online shopping behaviors. Electronic Commerce Research and Applications, 5, 295-304.

Zeiler, K., \& Plott, C. R. (2005). The willingness to pay-willingness to accept gap, the "endowment effect", subject misconceptions, and experimental procedures for eliciting valuations. The American Economic Review, 95, 530 e.v. 